\title{
SOME INTEROPERABILITY ISSUES IN THE DESIGNING OF WEB SERVICES : CASE STUDY ON CREDIT CARD
}

\author{
Kalpana Johari \\ Senior Lecturer \\ School of Information Technology \\ Centre for Development of Advanced Computing ,NOIDA \\ Arvinder Kaur \\ Associate Professor \\ University School of Information and Communication Technology \\ GGSIP University Dwarka, Delhi
}

\begin{abstract}
In today's environment most of the commercial web based project developed in the industry as well enumerous number of funded project/and studies taken as part of research oriented initiatives in the academia suffer from major technical issues as to how design, develop and deploy the Web Services that can run in variety of heterogeneous environments. In this paper we address the issues of interoperability between Web Services, the metrics which can be used to measure the interoperability and simulate the Online shopping application by developing the Credit Card Verification Software using Luhn's Mod 10 algorithm having Java Client written in NetBeans and the BankWebService in C\# .NET.
\end{abstract}

\section{GENERAL TERMS}

Algorithms, Design, Security.

\section{KEYWORDS}

RMI, CORBA, SOAP, WSDL, UDDI, OTP.

\section{INTRODUCTION}

Interoperability primarily refers to the seamless flow of the data and information across multiple Web Services hosted on single or multiple platform in a heterogeneous environments. One of the most pertinent question that often popup is to how to defined a "Web Service". A Few definition's have been suggested in [1], [2],[3] but it can be defined in more simpler terms as "Service that caters to other Services" that is hosting of multiple applications comprising of humongous data and information on a single platform on the Web using open standards like XML (Extensible Markup Language) [18] , SOAP (Simple 
International Journal on Web Service Computing (IJWSC), Vol.4, No.4, December 2013

Object Access Protocol) [19] and WSDL(Web Services Description Language) [20] and UDDI(Universal Description Discovery and Integration)[21]. As per W3C [World Wide Web Consortium] the Web Service can be defined as "A Web service is a software system designed to support interoperable machine-to-machine interaction over a network. It has an interface described in a machine-process able format (specifically WSDL). Other systems interact with the Web service in a manner prescribed by its description using SOAP messages, typically conveyed using HTTP with an XML serialization in conjunction with other Webrelated standards". One of the most important things to be kept in mind while understanding the concept of Web services is that Web Service is never going to be used directly by the human being(s).In fact all the information available through the web service is primarily meant for the software as it is the software that directly communicates with the web service and not the human beings. To our knowledge and understanding it is first such paper that not only addresses the issue of interoperability but also design Web Service in ASP.NET that caters to the query received from JAVA Client.

\section{RELATED WORK}

Chidamber and Kemerer [4] introduced the Response for Class (RFC) as a measure of the number of functions or methods that can potentially be executed in response to a message received by an object of that class. Choi and Lee [5] proposed a dynamic coupling metrics which can be used to accurately measure the coupling between the classes. Perepletchikov et al.[6] suggested a set of metrics for quantifying the structural coupling of design artifacts in service-oriented systems. Qian et al. [7] proposed a practical guide for evaluating decoupling between service- oriented components in the service composition such as Business Process Execution Language (BEPL). Quynh and Thang [8] proposed a collection of metrics to measure service's quality according to its usability of coupling. In their paper they discussed how the coupling metrics can be used to accurately measure the maintainability, reliability, testability and reusability of services. Li and Henry [9] illustrated the Message Passing Coupling (MPC) as the count of the number of send statements that are present in methods of on e class linked to other set of classes. They emphasized that Coupling between Object Classes should be viewed as the count of the number of classes to which it is coupled.

\section{INTEROPERABILITY IN EXISTING TECHNOLOGIES}

The Web Services should be interoperable to an extent that the classes, Arrays and Structures designed and developed using J2SE (Java 2 Standard Edition), or J2ME (Java 2 Mobile Edition), or J2EE(Java 2 Enterprise Edition) architecture should be able to communicate with the Array, Classes and Structures designed in the C\#(C sharp).NET application. In the same way their should be seamless flow of data between Applets designed in J2SE to Midlets designed in J2ME to Servlets designed in J2ME. The Same data or information if needed should be made available to the application designed in VB.NET or ASP.NET. J2EE offers two architecture's for the web services designed to exploit the concepts of distributed computing viz. RMI(Remote Method Invocation) and CORBA (Common Object Request Broker Architecture).RMI is primarily use for carrying out the JAVA - JAVA communication that is at both the ends of the application, the programs are written in JAVA so no issues of the interoperability's arise between the applications.RMI uses the concept of Remote Interfaces, Remote Objects, Stubs and Skeletons to carry out the communication between Client and server Programs written in JAVA. However the CORBA architecture which is a standard defined by the Object Management Group is primarily used for carrying out communication between the Java application and the non-Java application such as those application designed in the COBOL, Pascal, FORTRAN,ALGOL,C++, and C\#.NET etc. CORBA uses special files 
International Journal on Web Service Computing (IJWSC), Vol.4, No.4, December 2013

called as interface definition language (IDL) to specify the interfaces which objects present to the outer world applications . CORBA then specifies a mapping from IDL to a specific implementation language like C++ or JAVA. Standard mappings exist for C,C++, Ada, Simula, Smalltalk, Python, Ruby on Rails. So effort is always to go in for the seamless connectivity between JAVA and C\#.NET application.

\section{ISSUES IN THE INTEROPERABILITY OF WEB SERVICES}

In our paper we raise one of the biggest problem related to the interoperability of the Web Services at the implementation level is the incompatibilities in terms of the data types supported by the programming languages like JAVA and C\#. The Problem of incompatibilities arises in various ends due to the incompatibilities not only in terms of data types but also in terms of following listed incompatibilities between following three programming languages namely $\mathrm{C}++, \mathrm{JAVA}$ and $\mathrm{C \#}$

Table 1. Incompatibilities between the programming languages :-

\begin{tabular}{|c|c|c|c|c|}
\hline S.No & $\begin{array}{l}\text { Entity } \\
\text { Name }\end{array}$ & $\mathrm{C}++$ & JAVA & C\# \\
\hline 1 & DYNAMIC ARRAYS & NO & Yes & Yes \\
\hline 2 & VECTORS & No & Yes & No \\
\hline 3 & STRUCTURE & YES & $\mathrm{NO}$ & NO \\
\hline 4 & POINTERS & YES & $\mathrm{NO}$ & $\mathrm{NO}$ \\
\hline 5 & MULTIPLE INHERITANCE & YES & $\mathrm{NO}$ & NO \\
\hline 6 & INTERFACES & $\mathrm{NO}$ & YES & YES \\
\hline 7 & WRAPPER CLASSES & $\mathrm{NO}$ & YES & $\mathrm{NO}$ \\
\hline 8 & APPLETS & $\mathrm{NO}$ & YES & $\mathrm{NO}$ \\
\hline 9 & FINAL CLASSES & $\mathrm{NO}$ & FINAL & SEALED \\
\hline 10 & DELEGATES & $\mathrm{NO}$ & NO & CLASS \\
\hline 11 & MULTI- THREADING & $\mathrm{NO}$ & YES & YES \\
\hline 12 & EXCEPTION HANDLING & $\begin{array}{c}\text { YES (try, } \\
\text { catch and throw) }\end{array}$ & $\begin{array}{l}\text { YES (try, } \\
\text { atch }, \text { throw, } \\
\text { throws, finally) }\end{array}$ & $\begin{array}{c}\text { YES(try, catch, } \\
\text { Throw , throws, finally) }\end{array}$ \\
\hline 13 & PERSISTENCE & $\mathrm{NO}$ & $\begin{array}{c}\text { YES using } \\
\text { the Synchronization } \\
\text { keyword }\end{array}$ & YES \\
\hline 14 & FRIEND CLASSES & YES & $\mathrm{NO}$ & $\mathrm{NO}$ \\
\hline 15 & FRIEND FUNCTION & YES & $\mathrm{NO}$ & $\mathrm{NO}$ \\
\hline 16 & $\begin{array}{l}\text { DATABASE } \\
\text { CONNECTIVITY }\end{array}$ & $\begin{array}{l}\text { YES } \\
\text { (through DB- } \\
\text { Libraries) }\end{array}$ & $\begin{array}{l}\text { YES (thru } \\
\text { JDBC and } \\
\text { HIBERNATE) }\end{array}$ & $\begin{array}{l}\text { YES( thru ADO. } \\
\text { NET) }\end{array}$ \\
\hline 17 & $\begin{array}{l}\text { PREPROCE } \\
\text { SSOR DIRECTIVE }\end{array}$ & YES & $\begin{array}{l}\text { YES(thru } \\
\text { Packages) }\end{array}$ & Yes(thru Name spaces) \\
\hline
\end{tabular}


International Journal on Web Service Computing (IJWSC), Vol.4, No.4, December 2013

\begin{tabular}{|c|c|c|c|c|}
\hline 18 & $\begin{array}{l}\text { PURE VIRTUAL FUNCTION } \\
\mathrm{S}\end{array}$ & YES & $\mathrm{NO}$ & $\mathrm{NO}$ \\
\hline 19 & $\begin{array}{l}\text { OPERATOR } \\
\text { OVERLOADING }\end{array}$ & YES & NO & NO \\
\hline 20 & $\begin{array}{l}\text { STANDARD } \\
\text { TEMPLATE LIBRARY }\end{array}$ & YES & NO & NO \\
\hline 21 & LINKING TYPE & STATIC & $\begin{array}{l}\text { RUNTIME } \\
\text { /DYNAMI C }\end{array}$ & $\begin{array}{l}\text { RUNTIME } \\
\text { /DYNAMIC }\end{array}$ \\
\hline 22 & CHARACTER SET & $\begin{array}{l}\text { ANSI/ } \\
\text { ASCII }\end{array}$ & UNICODE & $\begin{array}{l}\text { UNICODE/ UCS( } \\
\text { Universal Character }\end{array}$ \\
\hline 23 & WEB SERVICES SUPPORT & $\mathrm{NO}$ & $\begin{array}{l}\text { YES(thru } \\
\text { SERVLET S and } \\
\text { JSP) }\end{array}$ & $\begin{array}{l}\text { YES } \\
\text { (thru ASP. NET) }\end{array}$ \\
\hline 24 & SOCKET PROGRAMMING & $\begin{array}{l}\text { YES(Possible } \\
\text { through UNIX } \\
\text { libraries) }\end{array}$ & $\begin{array}{l}\text { YES(through } \\
\text { Socket and } \\
\text { ServerSocket } \\
\text { classes) }\end{array}$ & $\begin{array}{l}\text { YES(through } \\
\text { built DLL) }\end{array}$ \\
\hline 25 & $\begin{array}{l}\text { ARBITRARY SIZED } \\
\text { INTEGERS }\end{array}$ & $\mathrm{NO}$ & $\begin{array}{l}\text { Reference type : } \\
\text { No Operator }\end{array}$ & YES \\
\hline 26 & $\begin{array}{l}\text { ARBITRARY SIZED } \\
\text { DECIMALS }\end{array}$ & $\mathrm{NO}$ & $\begin{array}{l}\text { Reference type } \\
\text { No Operator }\end{array}$ & $\mathrm{NO}$ \\
\hline
\end{tabular}

\section{METRICS FOR INTEROPERABILITY OF WEB SERVICES}

\subsection{Adherence to the standards}

The effort should always be laid on designing a Web Service that strictly conforms to norms and standards of WS-I (Web Services Interoperability Organization norms and W3C (World Wide Web) Consortium.

If we want to measure how interoperable a web service is that it should be measured in terms of it's adherence or deviation to the existing set of norms and standards. If a web service closely follows these standard set of Guidelines and norms then it is one which is highly interoperable and if does not then it is considered to be loosely interoperable.

\subsection{Number of User - Defined Data types}

While designing a Web Service efforts should be made in the direction of designing a Web service that uses maximum number of the fundamental data types and least number of user defined or derived data types. The Web Service which is designed using minimum number of derived data types then it is considered to be highly interoperable.

\subsection{Nesting of Web Services :-}

While designing the Web Service every effort should be made that all the information required by the said web service should be provided at one place under single umbrella that is all the functionality be defined under the functions defined in once class and less number of inner classes, anonymous inner classes (as in JAVA), abstract classes and nesting of classes should be used. 


\subsection{Request-Response Paradigm :-}

Number of request response messages being exchanged between the Service Subscriber (the client Software requesting Program) and the Web Service Publisher that is the Web Service, hosted on the Web Server and designed to handle multiple client request in a typical n-Tier Client Service application.

\subsection{Accessibility:}

A Web service should be accessible to one and all and it should be designed in such a manner that it strictly conforms to the Web Content Accessibility Guidelines 1.0 [12] and the standards for defined for Web Accessibility Initiative [13].

\subsection{Availability:-}

The Web Service should be designed to host millions of request around the clock on $24 \times 7 \times 365$ basis. This availability is the directly linked to the probability that the system is up and related to reliability [1]. An example of this metric is the Time-to-Repair that calculates the time it takes to repair the Web Service and to bring it back in operational state.

\subsection{Security:}

A Web Service needs to be secure from the on-site and on line attacks of hackers and crackers. Effort can be made to make a Web Service secure and less vulnerable by incorporating the light weight cryptographic algorithms.

\section{APPLICATIONS OF WEB SERVICE :-}

We can design the Web Service for variety of applications few of which can be described as follows :-

1) In Retail Stores :- In Retails Stores where in we can design the POS (Point of Sales) Application Software in JAVA and another application designed in VB.NET or C\#.NET that interfaces with Bar Code Reader to read the Bar Code Number from the Items (such as Cold Drink and NoteBooks ) etc.

2) QR Codes (Quick Response Code) consisting of Application designed in JAVA and the actual reading/fetching and storage of the information is coded in VB.NET or ASP.NET.

3) ReCharge WebSite :- The Application of the WebSite that accepts the mobile number can be designed in JAVA and the Application that does the task of recharge and the credit card verification can be designed in ASP.NET.

4) Online Portals and Vortals catering to different services like online music store and gaming sites et al.

\section{DESIGNING OF WEB SERVICE}

In order to depict the interoperability between the Web Services, We design a Web Service based application called Credit Card Verification Process that uses the Luhn's Mod 10 Algorithm[15]. We designed two classes one called as Credit Card class that serves as JAVA Client written in Net Beans[16] and other the Bank Class designed as Bank Web Service in C\#/ ASP.NET[17].The detailed steps performed in designing of the web service are listed in table 2 and the subsequent snapshots/images designed using JAVA Programming language in Net Beans and C\#.NET are schematically represented through figures $1-7$. 
International Journal on Web Service Computing (IJWSC), Vol.4, No.4, December 2013

Table 2: Steps in the designing of Credit Card based Service

\begin{tabular}{|c|c|c|c|c|c|}
\hline S. No & Steps & Validation & Description / Purpose & JAVA & $\begin{array}{l}\text { C\# } \\
\text { NET }\end{array}$ \\
\hline \multicolumn{6}{|c|}{ CUSTOMER APPLICATION REACHES BANK } \\
\hline 1 & $\begin{array}{l}\text { Customer Applies } \\
\text { to bank }\end{array}$ & $\begin{array}{l}\text { Custom er Details } \\
\text { need to be verified for } \\
\text { Example thru : Valid PAN } \\
\text { Card number or Driving } \\
\text { License number or Voter ID }\end{array}$ & $\begin{array}{l}\text { Customer details are } \\
\text { accepted and stored } \\
\text { the customer } \\
\text { in } \\
\text { of the DB }\end{array}$ & & YES \\
\hline 2 & $\begin{array}{l}\text { Customer } \\
\text { applies for Internet } \\
\text { Banking Option }\end{array}$ & $\begin{array}{l}\text { Bank class issues 6 digit } \\
\text { Unique MCSC (Master Card } \\
\text { Secure Code) or } \\
\text { VBV(Verified by VISA code) } \\
\text { to the customer }\end{array}$ & $\begin{array}{l}\text { VBV(Verified by VISA) and } \\
\text { MCSC (MASTER CARD } \\
\text { SECURED } \\
\text { CODE) need to be stored in } \\
\text { the customer table of the } \\
\text { Database }\end{array}$ & & Yes \\
\hline \multicolumn{6}{|c|}{ CUSTOMER GOES FOR ONLINE SHOPPING } \\
\hline 3 & $\begin{array}{l}\text { CC(Credit } \\
\text { Card) Class accepts } \\
\text { the Credit } \\
\text { Card No }\end{array}$ & $\begin{array}{l}\text { Checks whether the length } \\
\text { s of a Card number is } 16 \\
\text { digit or not }\end{array}$ & & Yes & \\
\hline 4 & $\begin{array}{l}\text { Next CC Class } \\
\text { checks whether } \\
\text { the number Valid } \\
\text { or Invalid }\end{array}$ & $\begin{array}{l}\text { To be verified by applying } \\
\text { the Luhn's Mod } 10 \\
\text { algorithm }\end{array}$ & & Yes & \\
\hline 5 & \begin{tabular}{|l|} 
Next CC \\
Class prompts \\
the user to enter \\
CVV (Credit Card \\
Verification Value \\
Number)
\end{tabular} & $\begin{array}{l}\text { To Check the length of } \\
\text { the number :- it should be } \\
\text { non-zero } \quad \text { and length } \\
\text { should not be greater then } 3\end{array}$ & & Yes & \\
\hline 6 & $\begin{array}{l}\text { Next the } \\
\text { CC enters the user } \\
\text { to enter the expiry } \\
\text { date. }\end{array}$ & $\begin{array}{l}\text { To ensure that an the expiry } \\
\text { rdate should not be less } \\
\text { the or equal to current } \\
\text { date. }\end{array}$ & & Yes & \\
\hline 7 & $\begin{array}{l}\text { Next the CC Class } \\
\text { enters the user to } \\
\text { enter the Amount } \\
\text { for carrying out the } \\
\text { transaction } \\
\text { fordoing on line } \\
\text { shopping. }\end{array}$ & $\begin{array}{l}\text { s The Amount } \\
\text { of should be non- zero } \\
\text { en }\end{array}$ & & Yes & \\
\hline 8 & $\begin{array}{l}\text { The CC } \\
\text { number now travels } \\
\text { safely thru the } \\
\text { Internet to reach } \\
\text { the Bank Class }\end{array}$ & & $\begin{array}{l}\text { To } \\
\text { make sure the information is } \\
\text { safe it is encry pted thru DES } \\
\text { ALGORIT HM/ AES ALG } \\
\text { ORIT HM }\end{array}$ & Yes & \\
\hline
\end{tabular}


International Journal on Web Service Computing (IJWSC), Vol.4, No.4, December 2013

\begin{tabular}{|c|c|c|c|c|}
\hline 9 & $\begin{array}{l}\text { A Verified } \\
\text { Credit Card No } \\
\text { is send as input } \\
\text { to Bank class } \\
\text { where } \\
\text { check is made to } \\
\text { check that if } \\
\text { customer is } \\
\text { have sufficient } \\
\text { funds to carry } \\
\text { out the transaction }\end{array}$ & $\begin{array}{l}\text { The Amount } \\
\text { should be non- zero. }\end{array}$ & NO & $\begin{array}{l}\text { Bank } \\
\text { class } \\
\text { in C\# } \\
\text {.NET }\end{array}$ \\
\hline 10 & $\begin{array}{l}\text { If the } \\
\text { Customer } \\
\text { have sufficient } \\
\text { funds then the } \\
\text { Bank class } \\
\text { prompts the } \\
\text { customer to enter } \\
\text { MCSC(Master } \\
\text { Card Secure } \\
\text { Code) or } \\
\text { VBV(Verified by } \\
\text { VISA code) }\end{array}$ & $\begin{array}{l}\text { This Code } \\
\text { should match with the } \\
\text { code issued in Step 2. }\end{array}$ & $\mathrm{NO}$ & $\begin{array}{l}\text { Bank } \\
\text { class } \\
\text { in C\# } \\
\text {.NET }\end{array}$ \\
\hline 11 & $\begin{array}{l}\text { Next the Bank } \\
\text { class } \\
\text { generates a } \\
\text { unique } \\
\text { number called } \\
\text { OTP(One Time } \\
\text { Password) which } \\
\text { is send back to } \\
\text { the CC Class }\end{array}$ & $\begin{array}{l}\text { The number } \\
\text { should be non- zero and } \\
\text { length between } 1-6 \text {. }\end{array}$ & $\mathrm{NO}$ & $\begin{array}{l}\text { Bank } \\
\text { class } \\
\text { in C\# } \\
\text {.NET }\end{array}$ \\
\hline 12 & \multicolumn{4}{|c|}{ CC Class receives the OTP and allows the user to carry out transaction } \\
\hline
\end{tabular}

\section{SNAPShots OF WEB SERVICE}

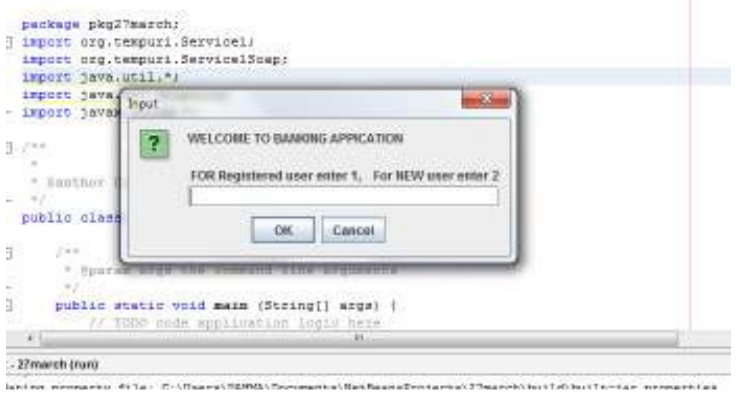

Fig 1 : Launching of Bank Application 
International Journal on Web Service Computing (IJWSC), Vol.4, No.4, December 2013

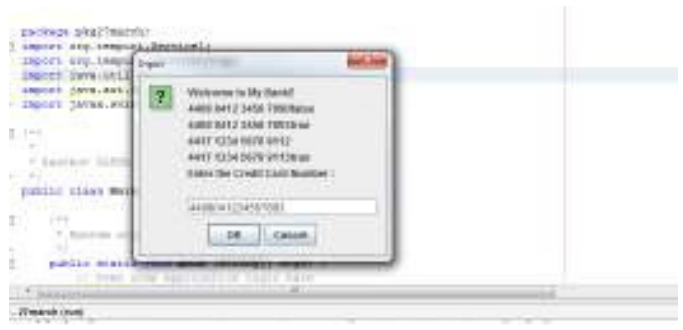

Fig 2 : Prompting the User to enter Credit Card Number

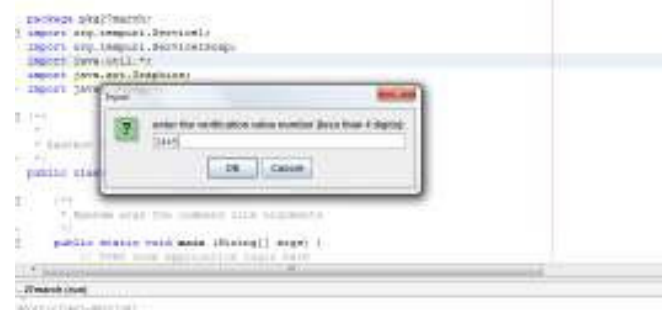

Fig 3 : Prompting the user to enter CVV number

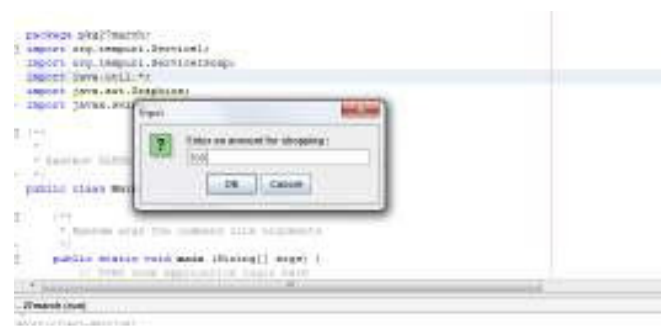

Fig 4 : Prompting the user to enter Shopping amount

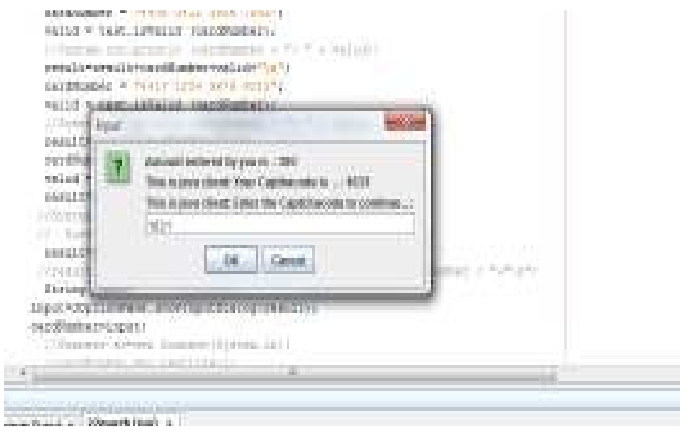

Fig 5 : Prompting the user to enter Shopping amount 


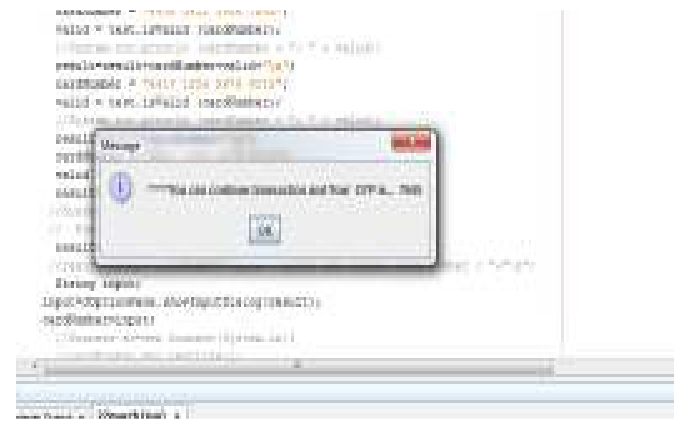

Fig 6 : Generation of OTP(One time Password)

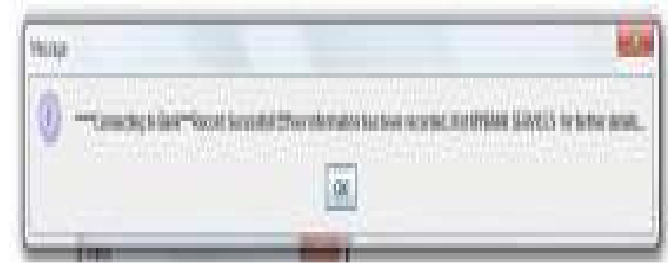

Fig 7 : Message Box for successful transaction

\section{INDUSTRY SUPPORT : WS-I INITIATIVES}

Today Web services are packaged in the WRF (Web Services Resource Framework) [Microsoft document] at includes the XML, SOAP and the WSDL and UDDI (Universal Description Discovery and Integration) et al. In order to achieve high level of interoperability between the different platforms and technologies an organization by the name of Web Service Interoperability [WS-I] [14] has been founded .WS-I is an open industry organization chartered to establish Best Practices for Web services interoperability, for selected groups of Web services standards, across multiple platforms, operating systems and programming languages. The WS-I Basic Profile establishes core Web services specifications (SOAP, WSDL, UDDI,XML Schema, HTTPS) that should be used together to develop interoperable Web services. To date, WS-I has produced the Basic Profile 1.0 and 1.1. [14]

\section{ACKNOWLEDGEMENT}

The author wishes to express their sincere gratitude to the administration of Centre for Development of Advanced Computing, NOIDA and Guru Gobind Singh Indraprastha University, DELHI for providing the academic environment to pursue research activities.

\section{FUTURE WORK}

We propose to develop many more web services and identify more important metrics which can be used to measure the interoperability between the Web Services. We also propose to develop secure and robust Web services which are not prone to the various Active and Passive Attacks .The security is enhanced by using various Symmetric and As symetric Cryptographic Algorithms such as DES,AES,RSA and RC4 algorithm provided as part of 
International Journal on Web Service Computing (IJWSC), Vol.4, No.4, December 2013

Java Cryptography Architecture and Java Secure Socket Extension.

\section{REFERENCES}

[1] Mohamad Ibrahim Ladan.: 2011. Web Services Metrics: A Survey and A Classification International Conference on Network and Electronics Engineering IPCSIT vol.11 (2011) (C) (2011) IACSIT Press, Singapore.

[2] Sujala D Shetty , Dr S Vadivel.2009 .Interoperability issues seen in Web Services In IJCSNS International Journal of Computer Science and Network Security, VOL.9 No.8, August 2009

[3] Nishith Pathak : Pro WCF 4: Practical SOA Implementation, (2011) Second Edition. ACTA Press

[4] S. R. Chidamber and C. F. Kemerer, "A Metrics Suite for Object Oriented Design," IEEE Trans. Softw. Eng., vol. 20,

[5] Choi, M. and J. Lee. 2007. A dynamic coupling for reusable and efficient software systems. Proceedings IEEE International Conference on Software Engineering Research, Management and Applications, Busan, South Korea, pp 720-726.

[6] Perepletchikov et al.2007. Coupling metrics for predicting maintainability in service-oriented designs. Proceedings of the 18th Australian Software Engineering Conference Melbourne, VIC Australia, pp 329-340.

[7] Qian et al. 2006. Decoupling metrics for services composition. Proceedings of the 1st IEEE/ACIS int'l conference on computer and information science, Honolulu, HI USA, pp 44-47.

[8] Quynh, P. T., and H. Q. Thang.2009. Dynamic coupling metrics for service oriented software. Int'1 Journal on Computer Science Engineering, 3 pp 282-287.

[9] Li, W. and S. Henry.1994. Object oriented metrics that predict maintainability. Journal of System Software, 23, 1993, pp111-122.pp. 476-493

[10] http://www.w3.org/DesignIssues/WebServices.html

[11] http://gdp.globus.org/gt4-tutorial/multiplehtml/ch01s02.html

[12] www.w3.org/TR/WCAG10

[13] www.w3.org/WAI

[14] http://www.ws-i.org/Docs/ws-i_faq_01.pdf]

[15] http://www.beachnet.com/ hstiles/cardtype.html

[16] http://netbeans.org/

[17] .http://www.asp.net/

[18] http://netbeans.org/

[19] http://www.w3.org/TR/SOAP

[20] http://www.w3.org/TR/WSDL

[21] http://www.w3.org/TR/UDDI 